\title{
Pengaruh Model Pembelajaran Generatif Dengan Metode PQ4R Melalui Scaffolding Terhadap Kemampuan Pemecahan Masalah Fisika Peserta Didik
}

\author{
Sri Maryani*, Hairunnisyah Sahidu, Sutrio \\ Program Studi Pendidikan Fisika, Universitas Mataram \\ *Email: maryanisri02@gmail.com
}

Received: 17 Desember 2019;

Accepted: 9 April 2020;

Published: 15 April 2020

DOI: http://dx.doi.org/10.29303/jpft.v6i1.1562

\begin{abstract}
Student often found that physics full of difficulty by using many equations to solve some problems and this lead to the decreased of problem solving ability in physics. One of the ways that suggested to increase problem solving in physics is using generative learning combined with $P Q 4 R$ method and scaffolding. Because of that, this research aim to discover the influence of generative learning with $P Q 4 R$ method through scaffolding toward ability to solve problem in physics. The type of this study is quasi experimental with non-equivalent control grup design with pretest-postest. Sampling was done by purposive sampling technique with XI MIA 2 as the experimental class and XI MIA 3 as the control class. The experimental class in this study was given generative learning with PQ4R method and scaffolding, while the control class was given conventional learning as the treatment. The results of ability to solve problem was obtained by essay test which consist 7 items and analyzed using t-test polled varians. Data analysis show that Ho was refused and the Ha was accepted. Therefore, there was an effect of generative learning with PQ4R method through scaffolding toward problem solving in physics.
\end{abstract}

Keywords: generative learning; PQ4R method; scaffolding; problem solving

PENDAHULUAN

Belajar diartikan sebagai suatu kegiatan yang menghasilkan perubahan dalam diri individu. Perubahan yang dihasilkan dari hasil kegiatan belajar mengarah pada segi pengetahuan maupun sikap dari pelajar. Pembelajaran yang menghasilkan produk positif dikatakan sebagai pembelajaran efektif.

Kefektifan dalam belajar dapat diketahui dengan mengukur dua sisi, yakni proses dan hasil belajar. Kegiatan belajar menghendaki peserta didik untuk mampu menyelesaikan permasalahan yang diberikan selama pembelajaran berlangsung maupun ketika evaluasi dilakukan. Fisika merupakan salah satu mata pelajaran dalam kategori eksak yang dapat digunakan oleh pelajar untuk mengukur tingkat kemampuan peserta didik dalam menyelesaikan suatu permasalahan.
Kemampuan pemecahan masalah merupakan salah satu aspek kemampuan berpikir tingkat tinggi dalam pembelajaran fisika. Pemecahan masalah diartikan sebagai suatu proses untuk menghilangkan masalah yang ada, yang di dalamnya terdapat hubungan atau konsep-konsep yang diperolehnya dalam memecahkan masalah (Sambada, 2012).

Berdasarkan hasil observasi yang telah dilakukan, dapat dikatakan kemampuan pemecahan masalah fisika peserta didik kelas XI MIA SMA tergolong rendah. Kondisi peserta didik masih banyak yang kurang dalam persiapan belajar. Hal ini dilihat dari terbatasnya literatur belajar fisika dan pengetahuan awal yang rendah. Serta proses belajar yang terjadi dalam kelas belum efektif sebab peserta didik cenderung tidak memperhatikan penjelasan yang diberikan. Berdasarkan permasalahan tersebut, maka diperlukan model dan metode 
pembelajaran serta bantuan belajar yang sekiranya dapat digunakan untuk menunjang peningkatan kemampuan pemecahan masalah fisika peserta didik.

Model pembelajaran yang dapat digunakan untuk meminimalisir permasalahan tersebut salah satunya adalah model pembelajaran generatif. Model pembelajaran generatif merupakan model pembelajaran yang berpusat pada peserta didik. Model ini mengintegrasikan pengetahuan awal yang dimiliki dengan pengetahuan baru yang diperoleh dari sasaran belajar. Osborne dan Wittrock menyatakan bahwa pembelajaran dengan menggunakan model generatif dapat membangun keaktifan peserta didik dalam kegiatan belajar serta mengkonstruksi makna dari informasi pengetahuan awal dan pengalaman yang dimiliki peserta didik (Hakim, 2014). Pembelajaran generatif ini terdiri dari 4 tahapan, yaitu persiapan, pemfokusan, tantangan, dan aplikasi Sugiana et al. (2017).

Selain dengan menggunakan model pembelajaran generatif kemampuan dalam memecahkan masalah fisika dapat ditingkatkan dengan mengkombinasikan metode serta bantuan dalam belajar. Metode dan bantuan yang menguntungkan dapat meminimalisir kekurangan pada model pembelajaran. Metode pembelajaran yang digunakan dalam penelitian adalah metode PQ4R dengan bantuan berupa scaffolding.

Metode PQ4R merupakan metode yang membantu peserta didik memahami dan mengingat materi yang dibaca melalui tahapan preview, question, read, reflect, recite, dan review (Trianto, 2015). Penelitian yang telah dilakukan oleh Hendi (2017) membuktikan bahwa metode PQ4R mampu meningkatkan kinerja memori dalam memahami substansi teks. Peserta didik yang belajar dengan menggunakan metode ini memiliki rata-rata kemampuan pemecahan masalah matematika lebih baik dibandingkan dengan pembelajaran ekspositori.

Selain dengan model pembelajaran generatif yang dipadukan dengan metode PQ4R peserta didik akan lebih mudah memecahkan masalah bila diberi bantuan dalam belajar. Bantuan yang diberikan adalah scaffolding (bantuan berjenjang). Berdasarkan teori belajar Vygotsky tentang zona perkembangan proksimal, membahas jarak antara tingkat perkembangan aktual dengan tingkat perkembangan potensial dapat dilakukan dengan pemberian scaffolding (Amanah et al. 2017). Santrock mengungkapkan bahwa ZPD menangkap keterampilan kognitif anak yang sedang dalam proses kematangan dan hanya dapat dicapai dengan bantuan seorang yang lebih terampil. Selama sesi pengajaran, seseorang yang lebih terampil (guru atau teman sebaya yang lebih ahli) menyesuaikan jumlah bimbingan sesuai dengan kinerja anak yang ada (Rusli et al. 2014).

Bantuan semacam ini sesuai dengan karakteristik fisika yang memiliki tingkat kesulitan tinggi. Scaffolding akan menjembatani pengetahuan awal siswa dengan prestasi belajar yang hendak dicapai, dengan mengurangi kesulitan tugas-tugas melalui penerapan keterampilan secara bertahap. Seperti yang diungkapkan oleh Sugiarto dalam Andi et al. (2015), scaffolding dapat diterapkan dalam pembelajaran dengan memberikan LKS dengan pendekatan scaffolding yang digunakan sebagai sumber belajar siswa.

Penggunaan kombinasi model pembelajaran generatif dengan metode PQ4R melalui pemberian scaffolding jarang ditemui terlebih jika terkait dengan studi fisika. Pembelajaran ini memberikan beberapa sarana yang menunjang peserta didik untuk lebih aktif menemukan konsep yang hendak dipelajari, terutama dengan 
metode PQ4R yang menghendaki peserta didik untuk membaca literatur yang telah disediakan dan menemukan ide pokok dalam sub-bab yang dipelajari melalui kegiatan membaca dan membuat beberapa pertanyaan. Berdasarkan pertimbangan tersebut, maka penggunaan kombinasi model dan metode ini serta bantuan scaffolding dirasa tepat untuk diterapkan di SMA Negeri 1 Labuapi. Peneliti berharap penggunaan model pembelajaran generatif dengan metode PQ4R dan berbantuan scaffolding mampu meningkatkan kemampuan pemecahan masalah peserta didik pada pembelajaran fisika di tingkat sekolah menengah atas.

\section{METODE PENELITIAN}

Penelitian kuasi eksperimen ini menggunakan desain non-equivalent control group design with pre-test and post-test. Penelitian ini melibatkan variabel bebas yaitu model pembelajaran generatif, metode PQ4R, dan scaffolding, variabel terikat yaitu kemampuan pemecahan masalah fisika, dan variabel kontrol yaitu waktu, guru yang mengajar dan materi ajar.

Penelitian dilakukan di SMA Negeri 1 Labuapi. Populasi dalam penelitian ini adalah seluruh peserta didik kelas XI SMA Negeri 1 Labuapi sebanyak 71orang yang terbagi dalam 3 kelas yaitu kelas XI MIA 1, MIA 2, dan MIA 3 dengan tiap kelas berkisar 20 sampai 25 orang peserta didik. Sampel penelitian ditentukan menggunakan purposive sampling, dimana adanya alasan khusus yang berkenaan dengan sampel yang diambil. Peneliti menggunakan kelas XI MIA 2 sebagai kelas eksperimen dan kelas XI MIA 3 sebagai kelas kontrol dengan pertimbangan kemampuan awal yang dimiliki oleh peserta didik masing-masing kelas tidak memiliki perbedaan yang cukup jauh dilihat dari observasi yang telah dilakukan sebelum pengambilan data.
Instrumen yang digunakan adalah tes kemampuan pemecahan masalah dengan teknik pengumpulan data berupa tes tertulis berbentuk soal uraian. Tes kemampuan pemecahan masalah berjumlah 7 soal. Indikator yang digunakan dalam tes kemampuan pemecahan masalah ini mengacu pada Sujarwanto (2014) dengan kategori pemecahan masalah (problemsolving) terdiri dari empat tahap, yaitu (1) mengenali masalah (identify), merencanakan strategi (set up), menerapkan strategi (execute), dan mengevaluasi solusi (evaluation). Sebelum digunakan dalam penelitian, instrumen tes kemampuan pemecahan masalah diuji validitas, reliabilitas, tingkat kesukaran dan daya beda soalnya. Uji analisis data dalam penelitian menggunakan uji-t polled varian dengan taraf signifikan $5 \%$ dan derajat kebebasan $n_{1}+n_{2}-2$. Data hasil kemampuan pemecahan masalah yang diperoleh dianalisis dengan $\mathrm{N}$-gain untuk mengetahui peningkatan antara kedua kelas setelah diberikan perlakuan.

\section{HASIL DAN PEMBAHASAN}

Tujuan dilakukannya penelitian ini adalah untuk mengetahui apakah terdapat pengaruh model pembelajaran generatif yang dipadukan dengan metode PQ4R melalui scaffolding terhadap kemampuan pemecahan masalah fisika peserta didik. Masing-masing kelas sampel diberikan perlakuan berupa penerapan model pembelajaran generatif dengan metode PQ4R serta bantuan scaffolding untuk kelas eksperimen, sedangkan untuk kelas kontrol diberikan pembelajaran fisika melalui model konvensional. Tes awal kemampuan pemecahan masalah diberikan kepada kedua kelas sebelum perlakuan diterapkan. Hal ini dilakukan untuk mengetahui kemampuan pemecahan masalah awal yang dimiliki olehpeserta didik pada kedua kelas. 
Tes kemampuan pemecahan masalah yang diberikan kepada peserta didik mengukur ranah kognitif dan penilaian disesuaikan dengan empat indikator pemecahan masalah. Data terkait hasil kemampuan pemecahan masalah fisika peserta didik sebelum dan sesudah perlakuan diperoleh melalui tes awal (pre-test) dan tes akhir (post-test). Berikut akan dipaparkan hasil penelitian pengaruh model pembelajaran generatif dengan metode PQ4R melalui scaffolding.

Berdasarkan tes awal yang telah dilakukan menggambarkan kemampuan pemecahan masalah awal fisika peserta didik baik pada kelas eksperimen maupun kelas kontrol masih rendah. Hal ini terlihat dari rata-rata tes kemampuan pemecahan masalahmasing-masing kelas, yaitu 33,52 untuk kelas eksperimen dan 35,33 untuk kelas kontrol. Nilai rata-rata tes awal yang

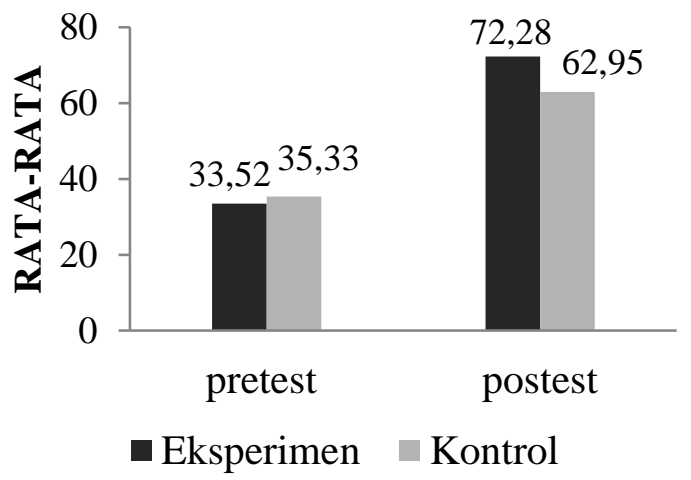

rendah dapat disebabkan karena peserta didik belum diberikan perlakuan serta belum memperoleh materi yang berhubungan dengan elastisitas bahan, sehingga mengakibatkan peserta didik sulit untuk melakukan integrasi pengetahuan yang dimiliki.

Gambar 1. Perbandingan Nilai Rata-Rata Kemampuan Pemecahan Masalah

Tes awal kemampuan pemecahan masalah fisika dianalisis dengan menggunakan uji-F untuk mengetahui homogenitas peserta didik terhadap materi sifat elastisitas bahan. Hal ini dilakukan untuk melihat sebaran data pada kedua kelas sebelum diberikan perlakuan. Setelah dilakukan tes awal, peneliti memberikan perlakukan berbeda pada masing-masing sampel penelitian. Peneliti melakukan tes akhir dengan materi, jumlah, serta skor yang sama dengan tes awal untuk mengukur pengaruh dari perlakuan yang diberikan pada kedua kelas. Hasil analisis data tes akhir yang telah dilakukan diperoleh nilai rata-rata kelas eksperimen lebih tinggi dibandingkan dengan kelas kontrol, yaitu 72,28 untuk kelas eksperimen dan 62,95 untuk kelas kontrol. Peningkatan rata-rata kemampuan pemecahan masalah fisika kelas eksperimen dan kelas kontrol disajikan pada Gambar 1.

Pada gambar 1 dapat dilihat bahwa model pembelajaran generatif dengan metode PQ4R dan bantuan scaffolding memberikan pengaruh yang lebih baik jika dibandingkan dengan pembelajaran konvensional, dalam kata lain peningkatan rata-rata yang diperoleh menunjukkan adanya pengaruh dari perlakuan yang diberikan baik pada kelas eksperimen maupun kelas kontrol.

Pengaruh perlakuan yang diberikan dapat diketahui dengan menggunakan uji analisis dengan uji-t. Sebelum melakukan uji-t pada hasil kemampuan awal dan kemampuan akhir, dilakukan uji normalitas dan uji homogenitas terlebih dahulu. Uji ini dilakukan dengan tujuan untuk memperoleh sampel yang berdistribusi normal, yaitu untuk uji normalitas dan uji homogenitas bertujuan untuk mengetahui apakah varians kelas eksperimen dan kelas kontrol sama. Setelah diuji, diketahui bahwa kedua kelas homogen dan terdistribusi normal baik pada tes awal maupun tes akhir. Sehingga dapat diartikan bahwa kemampuan awal peserta didik pada kedua kelas tersebut sama. Setelah diberi perlakuan berbeda data yang 
di dapat tetap homogen dan terdistribusi normal.

Selanjutnya dilakukan uji hipotesis menggunakan uji-t polled varians. Hasil uji hipotesis didapatkan harga $t_{\text {hitung }}=2,34$. Harga ini lebih besar dari harga $t_{\text {tabel }}=$ 2,021. Hal ini berarti terdapat pengaruh model pembelajaran generatif dengan metode PQ4R melalui scaffolding terhadap kemampuan pemecahan masalah fisika peserta didik. Hal ini sesuai dengan yang telah dipaparkan oleh Nurhayati, et al (2016) bahwa kemampuan pemecahan masalah siswa yang memperoleh pembelajaran dengan bantuan scaffolding lebih tinggi daripada siswa yang memperoleh pembelajaran langsung.

Dennen (2004) menyatakan bahwa bantuan berupa scaffolding ini sesuai dengan karakteristik mata pelajaran fisika yang memiliki tingkat kesulitan tinggi. Scaffolding juga berpengaruh terhadap siswa tidak hanya pada pengetahuan dan keterampilan, tetapi juga pada kemampuan menyelesaikan masalah (Haniin et al. 2015).

Kemampuan pemecahan masalah yang meningkat melalui penerapan model generatif dengan metode PQ4R dan scaffolding disebabkan karena peserta didik selama proses pembelajaran diberikan permasalahan sehari-hari terkait dengan fisika. Permasalahan yang terdapat pada LKPD telah diberikan petunjuk untuk mempermudah peserta didik menyelesaikannya. Peserta didik dalam menyelesaikan permasalahan juga tidak semerta-merta menuliskan jawaban yang sekiranya benar, namun dibiasakan untuk menuliskan acuan yang mendasari penyelesaian masalah tersebut (menuliskan konsep, ide, hukum, persamaan, atau representasi gambar jika diperlukan).

Hendi (2017) menyatakan bahwa pengalaman awal bisa dibangun melalui aktifitas membaca. Dengan kegiatan ini peserta didik akan memiliki stock of knowledge. Metode yang dapat digunakan untuk menunjang hal tersebut adalah menerapkan metode PQ4R dalam pembelajaran. Pelaksanaan belajar melalui metode ini dilakukan dengan memberikan handout materi elastisitas. Peserta didik diminta untuk membaca sekilas handout guna mendapatkan gambaran mengenai materi elastisitas. sebelum dilanjutkan pada tahap untuk menentukan pertanyaan. terkait dengan materi elastisitas. Hal ini dilakukan untuk menimbulkan rasa ingin tahu yang tinggi dari peserta didik serta kemampuan untuk mengingat lebih banyak konsep dari kegiatan membaca yang dilakukan.

Perpaduan dari model, metode, serta bantuan pembelajaran yang diuraikan dilakukan untuk meningkatkan tingkat kemampuan pemecahan masalah fisika peserta didik. Hakikat penting dari adanya kemampuan pemecahan masalah ini adalah agar konsep fisika yang telah dipelajari dapat bermakna. Keberhasilan dalam menyelesaikan permasalahan bergantung pada kesadaran peserta didik tentang apa yang mereka ketahui dan bagaimana mereka melakukannya, sehingga dalam proses pembelajaran fisika harus terjadi keseimbangan dalam melakukan dan berpikir (Yulianawati et al. 2016).

Peningkatan terhadap nilai kemampuan pemecahan masalah diukur sesuai dengan indikator masing-masing yang telah ditetapkan. Untuk mengetahui tingkat peningkatan per-indikator pemecahan masalah kedua kelas dilakukan dengan uji $\mathrm{N}$-gain. Hasil uji $\mathrm{N}$-gain untuk tiap indikator kemampuan pemecahan masalah diperoleh skor $\mathrm{N}$-gain kelas eksperimen lebih tinggi dibandingkan kelas kontrol yaitu 0,59 dan 0,43 secara berturut. Peningkatan masing-masing indikator dari pemecahan masalah juga dapat diketahui dari capaian peserta didik dengan 
membandingkan hasil awal dan akhir kedua kelas sampel penelitian. Berdasarkan kedua perolehan tersebut dapat dikatakan bahwa terdapat peningkatan kemampuan pemecahan masalah setelah diberikan perlakuan.

Tabel 1. Persentase Indikator Kemampuan Pemecahan Masalah (IPM)

\begin{tabular}{lccccc}
\hline \multicolumn{1}{c}{ Kelas } & Kemampuan & IPM-1 & IPM-2 & IPM-3 & IPM-4 \\
\hline Eksperimen & \multirow{2}{*}{ Awal } & $49 \%$ & $23 \%$ & $39 \%$ & $19 \%$ \\
Kontrol & \multirow{2}{*}{ Akhir } & $46 \%$ & $29 \%$ & $37 \%$ & $29 \%$ \\
Eksperimen & $84 \%$ & $68 \%$ & $75 \%$ & $60 \%$ \\
Kontrol & & $78 \%$ & $52 \%$ & $68 \%$ & $50 \%$ \\
\hline
\end{tabular}

Tabel 1 menunjukkan persentase skor rata-rata tes awal dan tes akhir untuk masing-masing indikator pemecahan masalah (IPM). Peningkatan terjadi pada masing-masing kelas untuk perolehan rerataan persentase IPM, baik IPM-1 sampai IPM-4 setelah diberikan perlakuan. Kenaikan yang tinggi dapat dilihat pada IPM-1 dan IPM-3 pada perolehan tes akhir oleh kelas eksperimen dan kelas kontrol. Meskipun kedua kelas mengalami peningkatan persentase pada tes akhir, tetapi peningkatan persentase yang dialami oleh kelas eksperimen lebih tinggi dibandingkan dengan kelas kontrol.

IPM-1 (mengenali masalah) memiliki persentase paling tinggi baik pada kelas eksperimen maupun kelas kontrol dibandingkan dengan ketiga IPM lainnya. Pada indikator ini, peserta didik masih mampu untuk menganalisa soal dengan menuliskan besaran yang diketahui atau keadaan yang dihasilkan dari permasalahan secara umum. Untuk IPM-2 dan IPM-4 memperoleh persentase yang terbilang rendah dari IPM lainnya. Sebab pada IPM-2 banyak dari peserta didik yang tidak mencantumkan konsep yang menjadi acuan mereka untuk menjawab permasalahan (benar atau salah). Peserta didik yang mencantumkan teori, konsep atau gagasan dalam menjawab permasalahan mendapatkan skor sesuai dengan yang telah ditetapkan. IPM-3 mengenai kemampuan peserta didik untuk menerapkan strategi (execute) terbilang tinggi. Sebab peserta didik dapat dikatakan mampu menerapkan ide (persamaan atau teori) yang digunakan dalam menjawab permasalahan. Selanjutnya untuk IPM-4, beberapa jawaban dari peserta didik banyak yang menuliskan bahkan tidak menuliskan gagasan pendukung yang sesuai.

Hal-hal yang perlu dilakukan untuk meningkatkan skor pada IPM-2 sampai IPM-4 adalah melakukan penekanan saat pembelajaran terkait konsep yang mendasari suatu permasalahan terjadi, seperti analisis masalah fisika terkait dengan kehidupan sehari-hari peserta didik. Penekanan pada proses merancang pertanyaan oleh peserta didik juga penting untuk dilakukan. Selanjutnya membuat lingkungan belajar kondusif sehingga mendukung timbulnya kemampuan analisis peserta didik dalam memecahkan suatu permasalahan dengan tepat.

Temuan penelitian ini memperkuat beberapa penelitian sebelumnya yaitu penelitian oleh Mawaddah dan Anisah (2015) yang menyatakan bahwa pembelajaran matematika dengan model generatif terbukti dapat meningkatkan kemampuan pemecahan masalah matematis peserta didik. Penelitian Amanah et al. (2017) menyatakan bahwa bantuan berupa scaffolding yang diberikan bersamaan dengan model pembelajaran generatif dapat meningkatkan kemampuan peserta didik dalam memecahkan permasalahan terkait dengan fisika. Hasbiyalloh et al. (2017) juga 
melakukan penelitian terkait scaffolding yang disisipkan pada pembelajaran ekspositori yang berdampak positif terhadap peningkatan hasil belajar siswa. Serta dalam penelitian Hendi (2017) yang menyatakan bahwa metode PQ4R sangat cocok diterapkan dalam proses pembelajaran, sebab dapat membantu dalam memacu daya pikir dan nalar peserta didik yang berujung pada meningkatnya kemampuan pemecahan masalah matematika siswa. Penerapan metode ini dalam proses pembelajaran lebih menunjukkan adanya kemajuan dalam proses memecahkan masalah jika dibandingkan dengan menggunakan pembelajaran ekspositori.

\section{PENUTUP}

Berdasarkan uji hipotesis, dapat disimpulkan bahwa terdapat pengaruh model pembelajaran generatif dengan metode PQ4R melalui scaffolding terhadap kemampuan pemecahan fisika peserta didik. Selanjutnya, untuk saran yang dapat diberikan oleh peneliti adalah model pembelajaran generatif yang dipadukan dengan metode PQ4R dan bantuan scaffolding ini selayaknya dapat dijadikan pertimbangan untuk diterapkan dalam kegiatan pembelajaran guna meningkatkan kemampuan pemecahan masalah peserta didik. Namun, dalam penerapan metode ini diharapkan untuk memperhatikan karakteristik materi (tidak semua materi fisika cocok diajarkan menggunakan metode PQ4R), sehingga tujuan belajar yang dikehendaki dapat tercapai.

\section{REFERENSI}

Amanah, P.D., Harjono, A., dan Gunada, I.W. 2017. Kemampuan Pemecahan Masalah dalam Fisika dengan Pembelajaran Generatif Berbantuan Scaffoldingdan Advance Organizer. Jurnal Pendidikan Fisika dan Teknologi, 3(1), 86-88.
Andi, H. J. dan Handayani, S. M. 2015. Pengaruh Model Pembelajaran GI dengan Scaffolding Terhadap Penguasaan Konsep Fisika. Jurnal Pemikiran Pamenelitian Pendidikan dan Sains, 3(6), 161.

Hakim, A. R., 2014. Pengaruh Model Pembelajaran Generatif Terhadap Kemampuan Pemecahan Masalah Matematika. Jurnal Formatif, 4(3), 199-200.

Haniin, K., Diantoro, M., dan Handayanto, S. K. 2015. Pengaruh Pembelajaran TPS Dengan Scaffolding Konseptual Terhadap Kemampuan Menyelesaikan Masalah Sintesis Fisika. Jurnal Pendidikan Sains, 3(3), 99.

Hasbiyalloh, A., Harjono, A., \& Verawati, N. (2017). Pengaruh Model Pembelajaran Ekspositori Berbantuan Scaffolding Dan Advance Organizer Terhadap Hasil Belajar Fisika Peserta Didik Kelas X. Jurnal Pendidikan Fisika dan Teknologi, 3(2), 173-180.

Hendi, A., 2017. Pengaruh Strategi Preview, Question, Read, Reflect, Recite, and Review (PQ4R) Untuk Meningkatkan Kemampuan Pemecahan Masalah Matematika Siswa. Prosiding Seminar Nasional Matematika dan Pendidikan Matematika. ISSN: 2579-9444.

Mawaddah, S. dan Anisah, $H$. 2015.Kemampuan Pemecahan Masalah Matematis Siswa Pada Pembelajaran Matematika dengan Menggunakan Model Pembelajaran Generatif (Generative Learning) di SMP.Jurnal Pendidikan Matematika, 3(2), 174.

Nurhayati, E., Mulyana, T., dan Martadiputra, B.A.P., 2016. Penerapan Scaffolding Untuk Pencapaian Kemampuan Pemecahan Masalah Matematis. Jurnal Penelitian Pendidikan dan Pengajaran Matematika, 2(2), 111. 
Rusli, M.A., Prabowo, Widodo, W., dan Usman. 2014. Pembelajaran Fisika Melalui Pemrosesan Top Down Berbasis ScaffoldingUntuk Melatihkan Keterampilan Berpikir Kritis. Jurnal Sainsmat, 3(1), 4-5.

Sambada, D. 2012. Peranan Kreativitas Siswa Terhadap Kemampuan Memecahkan Masalah Fisika dalam Pembelajaran Kontekstual. Jurnal Penelitian Fisika danAplikasinya, 2(2), 37-42.

Sugiana, I. N., Harjono, A., Sahidu, H., \& Gunawan, G. 2017. Pengaruh Model Pembelajaran Generatif Berbantuan Media Laboratorium Virtual Terhadap Penguasaan Konsep Fisika Siswa pada Materi Momentum dan Impuls. Jurnal Pendidikan Fisika dan Teknologi, 2(2), 62.

Sujarwanto, E., Hidayat, A., dan Wartono. 2014. Kemampuan Pemecahan Masalah Fisika Pada Modeling Instruction Pada Siswa SMA Kelas XI. Jurnal Pendidikan IPA Indonesia, 3(1), 67.

Trianto. 2014. Mendesain Model Pembelajaran Inovatif, Progresif, dan Kontekstual. Jakarta: Prenada Media.

Yulianawati, D., Novia, H., dan Suyana, I. 2016. Penerapan Pendekatan Metakognitif Dalam Upaya Meningkatkan Kemampuan Pemecahan Masalah Fisika Siswa SMA Pada Materi Gerak Harmonik Sederhana. Prosiding Seminar Nasional Fisika Dan Aplikasinya. ISSN:2339-065. 